\title{
The Chutnification of English in Salman Rushdie's Midnight's Children: A Stylistic Analysis
}

\author{
Deepa Thomas \\ Assistant Professor, Department of English, Deva Matha College, Kottayam, Kerala, India \\ E-Mail: deepatoms@gmail.com
}

\begin{abstract}
Salman Rushdie has been lauded for his energising use of language. In Indian writing in English, Rushdie is generally accepted as an initiator and catalyst of a style that saw English being used imaginatively and with ease. Rushdie's use of the expression "chutnification" epitomizes his use of language in the novels, with special reference to Midnight's Children. The process of chutnification of English provides a tasty flavour to Rushdie's works, which is obviously made possible through the abundant blending of Hindi and Urdu words with English, thereby reflecting India's hybrid culture. The present paper proposes to make a comprehensive attempt to scrutinise the linguistic experiments conducted by Rushdie in this novel. An examination of the language of Midnight's Children within the ambit of Stylistics, will yield a rich dividend, and an analysis and a study of this kind will add new insights to the novel.
\end{abstract}

Keywords: Chutnification, Hinglish, Midnight's Children, Stylistics, Language Learning

\section{INTRODUCTION}

Salman Rushdie's Midnight's Children has been variously described as a postmodern novel, Post-colonial novel, and a novel which uses techniques of magic realism, metafiction and historiography. Having won the Booker Prize, the novel has attracted the attention of many critics for its remarkable use of language. Not only is his language abundant in unusual collocations, wordplay, allusions, metaphors, etc., but it has an obvious 'Indian flavour' which is strongly felt by the reader, even if it is not so easy to pinpoint what exactly accounts for it. Language assumes a central focus in postcolonial studies. It served as a tool wielded by those in authority to exert control.

Much has been written on Rushdie over the years. Many works have evolved analysing the predominant concerns articulated in his novels. Many researchers have analysed his works from the theoretical perspective of post colonialism, diaspora etc. However, little has been written about his language so far. Some references to his linguistic creativity can be found within critical essays and books which focus predominantly on his themes. A study of Rushdie cannot ignore his linguistic genius (Richards, 2000). Therefore, one has to take into account the manner in which he reinvigorates narrative and the English language. Although not every reader will enjoy his novels in their entirety, it would be impossible for anyone to deny his extraordinary use of language.
By reworking the alien language to suit the needs and nuances of the mother language in terms of grammar, vocabulary and syntax, an 'english' is constructed which differs from the received standard (Ashcroft et al., 2008). In a similar vein, Rushdie comments on how writing in new englishes can be viewed as a salutary act of resistance, in the appropriation and re-forming of a colonial language to reflect the postcolonial experience. The innovativeness of Rushdie's English is prompted by a desire to capture the spirit of Indian culture with all its multiplicity and diversity. As a linguistic experimentalist, Rushdie attempts to destroy 'the natural rhythms of the English language' and to dislocate 'the English and let other things into it'(Chatterjee, 2004). Clyne (2011) states that Rushdie's Midnight's Children best illustrates his strategy of 'Indianising, revitalising and decolonising the English language’.

\section{HINGLISH LANGUAGE}

Rushdie, unlike the novelists who preceded him, uses the hybrid, pan-Indian "Hinglish" to communicate the worldview and emotions of his characters (Fries, 2005). It is very effective because it is easily recognizable as the speaking voice of the common man or woman in India. This was not so in the novels of Narayan, Rao and Anand (Girish, 2000). In their novels, we always had to consciously suspend our beliefs that the tongawalla or the sweeper were speaking in English. But if we look at this example from Midnight's Children, we won't find anything strange:

She (Padma) attempts to cajole me from my desk: "Eat, na, food is spoiling”. I remained stubbornly hunched on paper....Padma snorts. Wrist smacks across forehead. "Okay, starve, starve, who cares two pice" (89).Rushdie uses British English for the educated male narrator, Saleem, and "Hinglish" for Padma, Saleem's uneducated beloved. This gives us the knowledge that these characters belong to different social classes. While the British English highlights the stubborn moody character of Saleem, as Padma tries to cajole him and persuade him to eat much like an Indian wife is likely to do, her "snorts", and wrist smacks across forehead revel his and her frustration and his inflexibility. The Hinglish used here also suggests a number of things. First, the effect of both the sentences, -"eat na, food is spoiling" and "okay, starve, starve, who cares two pice" implies that Padma is not speaking English. The reason is 
the use of the word "na" in the first sentence and the grammatical "error" ("food is spoiling" rather than "the food is getting cold”) which are more likely to be used in the vernacular. Again, in the second sentence, the use of "starve" twice for emphasis definitely communicates that it is not an English utterance. In English, one never uses a word twice for emphasis. For example, "I sang while I worked". This usage of the same word twice in succession is more common in the vernacular-"Maine gaate gaate kaam kiya”. Thus, in a few sentences using some British English and some "Hinglish", Rushdie is able to convey a great deal about his character, their close relationship, personalities, emotions, social class, educational level and culture.

\section{USE OF VERNACULAR WORDS}

Khair (2005, p.24) claims that “ Rushdie is mostly trying to appropriate a kind of Indian English that his characters are supposed to speak while Rao is mostly translating the vernacular spoken by his characters”. This fact accounts for a lot of difference between the attitudes of these two writers towards English. True to his grain, Rushdie makes use of a number of Hindi, Urdu and Hindustani words, phrases and expressions in Midnight's Children. Such words, phrases and expressions form a long list, including 'ekdum' (at once), 'angrez' (Englishman), 'phut-aphut'(in no time), 'nasbandi' (sterlization), 'dhoban' (washerwoman), 'feringee' (the same as 'angrez'), 'baba' (grandfather), 'garam masala' (hot spices), 'rakshasas' (demons), 'fauz' (army), 'badmaas’ (badmen), ‘jailkhana’ (prison), ‘baap-rebaap’ (o, my father), 'jalebis' (a variety of sweet), 'barfi' (a sweet), 'bhel-puri' (a sort of tasty snack), and many others (Odlin, 2008). The use of such expressions provides an amount of authenticity and credibility to the novel. It also enhances the quantum of reality which is so much needed in an historical novel like Midnight's Children.

In short, "Rushdie took 'linguistic risks' that with utter abandon, defining them as getting away with the use of the mongrel street language of cities, daring to translate idioms and puns mediated by no apology, no footnote, no glossary” (Mukherjee, 2003, p.10). Though Mukherjee's contention that Rushdie 'get[s] away with the use of the mongrel street language of cities' is difficult to accept, as Rushdie occasionally resorts to film-songs and film-language in this novel, her observation that he is 'daring to translate idioms and puns mediated by no apology, no footnote, no glossary' is definitely sustainable. She commends Midnight's Children as: a theoretical discourse about nation, history and their narrativity, as the paradigmatic post-colonial text subverting the notions of received historiography and indigenising both the language and the narrative mode of the colonising culture, and as the quintessential fictional embodiment of the postmodern celebration of de-centring and hybridity. (Mukherjee, 2005, p.11)

The English of Rushdie is decidedly postcolonial and postmodern. It gives us glimpses into his conscious craftsmanship, which aims at decentring and hybridity. And his skill at 'decentring' and 'hybridity' is best seen when he, at the lexical level, employs some Latin and Arabic words. Some of the outstanding examples of this are: 'mucuna pruritis', ‘feronia elephanticus', 'sunt lacrimae rerum’ (all Latin), 'kam ma kam’, ‘fi qadin azzaman', ‘tilk al-gharaniq al', and ‘ula wa inna shafa ata-hunna la-turtaja’ (all Arabic).

\section{A. Unusual compound words}

Sometimes Rushdie combines words and phrases to make compounds, a style later imitated by Arundhati Roy in her The God of Small Things (1997). Such compounds are galore in Midnight's Children, such as 'overandover', 'updownup', ‘downdowndown', 'suchandsuch', 'noseholes', 'birthanddeath', 'what do you mean how can you say that', 'blackasnight', 'nearlynine', 'nearlynineyearold', 'almostseven', and 'godknowswhat'. (Odlin, 2008). These compounds display the extent of Rushdie's inventiveness and show his mastery of the English language. He employs it as he wishes it to suit his purpose. But the danger of deviations from the traditional English, especially in matters of grammar and syntax, lies in creating unwanted difficulties for readers. In a way, "Rushdie uses a highly stylized version of the English grapholect” (Khair, 2005, p.25). And as Ben Jonson said of Shakespeare, Rushdie is not a safe model for the future writers of English because of his ‘chutnification' of English. Rushdie uses slang - mostly Indian - very often in the text of Midnight's Children; for example, ‘funtoosh', 'goo', 'gora’, 'zenana', 'hubsee’, etc.

He does not stop here and proceeds to create new slang words like 'other pencil', 'cucumber', 'soo soos', and 'spittoon'. Thus, Padma (the heroine) says to Saleem Sinai (the hero/protagonist), "Now that the writery is done, let's see if we can make your other pencil work!" (p.11) here 'writery' is used for 'writing' and 'your other pencil' for male sex organ. The language has become both inventive and suggestive here.

\section{B. Misspellings of Words}

Occasionally, Rushdie resorts to deliberate misspellings of words. Examples are: 'unquestionabel', ‘straaange', 'existance', 'ees', etc. He also uses some incorrect words, from the grammatical viewpoint, such as 'mens', 'lifeliness', and 'informations'. All these deliberate misspellings point to the use of English by Indians in their daily lives. We also discover certain lapses of grammar in the novel, such as in 'August 15th, 1947'and 'June 25th, 1975', and no use of the article 'the' before 'Emergency'. Such lapses are, probably, deliberate in order to flout the traditionally accepted norms of grammar. The use of 'once upon a time' in the passage quoted above seems to be redundant, though it serves to create the impression of a fairy-tale. This kind of expression tends to create 'magic realism' in the novel, for Midnight's Children is both history and fantasy at the same time. 
In Midnight's Children, Rushdie tries “to destroy the notion of the purity or centrality of English by inventing new forms of existing English words or by effecting 'creative hybridization” (Mukherjee, 2004, p.12). Though one can find a number of examples of this in the text of the novel, some of them are given here: 'dislikeable', 'doctori', unbeautiful', 'sonship', 'memoryless', 'historyless', 'dupatta-less', 'chutnification', etc.

\section{Rushdie's use of English in Descriptive scenes}

Rushdie uses the English language to describe landscapes or actions so that these acquire a three dimensional cinematic quality. He draws on the visual, auditory, kinesthetic senses and conveys images, feelings and sounds in a way that render them immediate and experience able. In the passage quoted below, Saleem tries to show off to Evie that he has learnt how to ride a bike. Evie is his neighbor on whom he has a crush while Evie is soft towards Sonny. "roundandroundand.....finally, to please her (Evie), I stammered, 'Okay...... think I'm....... let me, and instantly I was on my own, she had given a farewell shove....I heard her shouting. The brake! Use the goddamn brake ya dummy!'-but my hands couldn't move, I had gone rigid as a plank, and there LOOK OUT in front of me was the blue two-wheeler of Sonny Ibrahim, collision course, OUTA THE WAY YA CRAZY ......(186-87)

The use of capital letters is to convey Saleem's inner dialogue and thoughts, and Rushdie's practice of joining three to four words without a hyphen is to communicate uninterrupted motion. This use of language is present in many passages of the book. When we look at the following description of the arrival of spring in Kashmir after a long snow-laden winter, we understand that the metaphor used is that of a newborn chick, emerging out of its eggshell, bringing with itself a sense of something new, young, fresh, just born:"The world was new again. After a winter's gestation in its eggshell of ice, the Valley had beaked its way out into the open, moist and yellow" (10).

\section{CONCLUSION}

Midnight's Children is regarded as a trendsetter. The sheer energy, the innovations in the English language, form, theme and range of this big novel had a stunning impact. Today this novel is regarded as a trendsetter because of the influence it has had on the Indian English novels written ever since. It's highly imaginative quality, its unconventional word-play, the disarranged syntax and spirited metaphors, its stunning fusion of oral narrative, history, fiction, non-fiction, journalism, Hindi film songs, fantasy, realism, and the stream of consciousness provide ample materials for research.

To conclude, Rushdie's numerous experiments with the English language have made Midnight's Children a highly challenging and complex work of fiction. Along with the content and its marvellous treatment, these linguistic experiments have enabled Rushdie to capture the topmost position among the winners of the Booker Prize over the past twenty-five years. His linguistic experiments in Midnight's Children, strange and startling at times as they are, have attracted readers and reviewers the world over, and have placed Indian English fiction on a sound footing in the present-day highly competitive literary scene.

\section{REFERENCES}

[1] Ashcroft, Ronald \& Nash, Walter. (2008). Seeing Through Language: A Guide to Styles of English Writing. Oxford, England: Blackwell Publishers.

[2] Brown, H. D. (2000). Principles of Stylistic Analysis. London, England: Longman.

[3] Brumfit, Christopher J. (2015). Language and Literature Teaching from Practice to Principle. Rosedale, New Zealand: Pearson Education.

[4] Byran, M. (2006). Stylistics Studies. Brisbane, Australia: Longman Publishers.

[5] Carey, J. W. (1989). Communication as Culture: Media and Society. New York, NY: Routledge.

[6] Chatterjee, Sisir Kumar. (2004). 'Chutnification: The Dynamics of Language in Midnight's Children' in K.B. Kumar (Ed.), Salman Rushdie's 'Midnight's Children': A Reader's Companion 252-53. New Delhi, India: Asia Book Club.

[7] Clyne, M. (2011). Language and Rushdie. London, England: BBC.

[8] Collier, A. (2008). Stylistics: An Introduction. Rosedale, New Zealand: Pearson Education.

[9] Finch, G. (2000). Linguistic terms and concepts. London, England: Macmillan Press.

[10] Fries, C.C. (2005). Teaching and Learning Hinglish as a Blend Language. Edinburgh, Scotland: Elsevier.

[11] Girish, G. (2000). Indian English Literature. New Delhi, India: Pearson Education

[12] Khair, Tabish. (2005). 'Language Problems of Dialogue and Mapping' in A.K. Malhotra (Ed.), Babu Fictions: Alienation in Contemporary Indian English Novels 110-11. New Delhi : India: Macmillan Publishers

[13] Mukherjee, Meenakshi. (2003). The Twice Born Fiction. New Delhi, India: Arnold-Heinemann.

[14] Odlin, T. (2008). Style and Stylistics of Rushdian Novels. Auckland, New Zealand: Random Press.

[15] Ranta, G. (2010). Stylistics Today: Between Theory and Practice. Sydney, Australia: Elsevier.

[16] Richards, J.C. (2000). A Reading of Rushdie. London, England: Longman.

[17] Rushdie, Salman. (2000). Midnight's Children. Oxford, England: Oxford University Press. 